\title{
ANALYSIS OF COMPLIANCE LEVEL OF NURSE PERSONAL PROTECTION USE IN ROYAL PRIMA GENERAL HOSPITAL
}

\author{
Sri Lestari Ramadhani Nasution ${ }^{1 *}$, Nadratul Ulya ${ }^{1}$, Sinta Ayu Setiawan ${ }^{2}$, Sri Wahyuni Nasution ${ }^{1}$ \\ ${ }^{1}$ Fakultas Kesehatan Masyarakat, Universitas Prima Indonesia, Sumatera Utara, Indonesia \\ ${ }^{2}$ Akbid Harapan Mulya Ponorogo, Jawa Timur, Indonesia \\ *Corresponding Author: srilestari_nasution@yahoo.com
}

\begin{abstract}
This study aimed to determine the level of compliance with personal protective equipment as prevention of work accidents. This research was conducted using quantitative methods with a crosssectional approach in the Emergency Unit and Intensive Care Unit at the Royal Prima General Hospital. The population of this study was nurses who worked in the Emergency Unit and officers in the intensive care unit of the Royal Prima General Hospital, with a total sample of 110 people using simple random sampling. Retrieval of research data using questionnaires and observation sheets as research measures. Analysis of research data used is Somers would like the analysis. The results showed a relationship between age and adherence to the use of PPE with $p=0.002$. There is no correlation between years of service and compliance with the use of PPE with p-value $=0.75$. There is a relationship between knowledge of compliance with the use of PPE with p-value $=0.009$. There is a relationship between attitudes towards compliance with the use of PPE with $p=0.002$. There is a relationship between the availability of facilities and compliance with the use of PPE with a p-value of 0.000 . There is a relationship between compliance training on the use of PPE with p-value $=0.004$. There is a control relationship to compliance with the use of PPE with $p$-value $=0.002$. The compliance of nurses working in the Emergency Unit and officers in the intensive care unit of the Royal Prima General Hospital in personal protective equipment (PPE) must still be improved with regular socialization and supervision by RSU Royal Prima.
\end{abstract}

Keywords: Behavior; Equipment Availability; Motivation; Compliance; Protective Equipment

\section{INTRODUCTION}

Hospitals are complex, expert-intensive, and capital-intensive health care institutions. Hospitals also use a lot of high-tech equipment, materials, and dangerous drugs. Health workers in hospitals are at risk for exposure to hazardous materials that can affect their health status. ${ }^{1}$

Health workers in hospitals are at high risk of being infected with diseases that can threaten their health and safety at work. WHO (World Health Organization) recorded cases of nosocomial infections globally, such as 66,000 cases of hepatitis B transmission, 16,000 cases of hepatitis C, and 1000 cases of HIV transmission. In Indonesia alone, the number of nosocomial infections still reaches $15.74 \%$, which is still relatively high compared to developed countries, ranging from $4.8-15.5 \%{ }^{2}$

Hospitals must have a program that can protect health workers and patients in hospitals from avoiding the danger of infection by carrying out Infection Prevention and Control activities in hospitals. Prevention and control of infectious diseases in hospitals can be done by increasing standard precautions including hand hygiene, use of PPE, prevention of sharp object injuries, safe waste management, cleaning, disinfection and sterilization of patient care equipment, and environmental cleaning and disinfection carried out by hospital staff. health workers to reduce the risk of spreading infection. ${ }^{3}$

Green stated that many factors influence a person's compliance behavior. The first is a 
predisposing factor which includes age, years of service, knowledge, attitudes, cultural system, and level of education. The second factor is the enabling factor which includes facilities and infrastructure/facilities. The third factor is a reinforcing factor which includes the attitude of health workers and applicable regulations. ${ }^{4}$

In practice, health workers' compliance in carrying out standard precautions, especially personal protective equipment, is still lacking. Of course, it can be dangerous for health workers to contract infections in hospitals. According to the monitoring report of the Infection Prevention and Control Team at the Royal Prima General Hospital, the average adherence to the use of personal protective equipment in 2018 was $88.4 \%$. However, this figure still does not meet the standard of quality indicators in hospitals, where the quality indicator is expected to be $100 \%$. Based on this, researchers are interested in researching the level of compliance with personal protective equipment in the Emergency Unit and officers in the intensive care unit of the Royal Prima General Hospital in 2019.

\section{MATERIAL AND METHODS}

This study uses a quantitative method with a cross-sectional approach for compliance with the use of personal protective equipment in the Emergency Unit and officers in the intensive care unit of the Royal Prima General Hospital. The population of this study was nurses in the Emergency Unit and officers in the intensive care unit of the Royal Prima General Hospital, with a total sample of 110 people obtained by simple random sampling method. The independent variables studied in this study were age, years of service, knowledge, attitudes, availability of facilities, training, and supervision-retrieving research data using questionnaires and observation sheets as research measuring tools. Analysis of research data used is Somers would like the analysis.

\section{RESULT}

Research this involving 110 nurse respondents in the Emergency Unit and officers in the intensive care unit of the Royal Prima General Hospital. The research sample was selected using a simple random sampling method so that all members of the population have the same opportunity to become the research sample. ${ }^{5}$

Women dominated characteristics of respondents based on gender in this study, $76.7 \%$ of the total population. Women dominate most nurses at RSU Royal Prima because the nursing profession requires precision and aesthetics that are identical to women. According to Balbeid, the health sector is still more dominated by the female sex, and health workers must have the ability to carry out treatment and must have a maternal instinct that is more owned by women. ${ }^{6}$

Characteristics of respondents based on age are dominated by the age range of 20-25 years, with $73.9 \%$ of the total population. At the same time, respondents with an age range of 26-30 years amounted to $26.1 \%$.

Characteristics of respondents based on years of service in this study were primarily respondents with a tenure of 24-30 months with a percentage of $33.3 \%$.

\section{DISCUSSION}

\section{Analysis Bivariate}

The Relationship Between Age and Compliance with The Use of Personal Protective Equipment

The results of the correlation analysis to test the first hypothesis (H1) in this study stated that age was associated with compliance with the use of personal protective equipment. This shows that the older the nurse, the better the compliance with personal protective equipment.

The results of this study are following the research conducted by Supiana with the results that there is a significant relationship between age and compliance with the use of personal protective equipment in midwives in midwifery services at RKIA Sadewa Yogyakarta. ${ }^{7}$ This is also following research conducted by Apriliuana, which states a very significant relationship between age and the behavior of using personal protective equipment in health workers at the Banjarbaru Regional General Hospital. ${ }^{8}$ However, the 
results of this study are not in line with the research conducted by Ibrahim, which shows that the level of compliance with the use of personal protective equipment between ages more than the mean age is the same as age more minor than the mean age so that it can be stated that there is no relationship between age and behavior. ${ }^{9}$ Compliance with the use of personal protective equipment in Cilegon city clinical laboratory officers. The age category in this study is based on the age division according to the Indonesian Ministry of Health, namely the age range of 20-25 years which is classified as late adolescence. At this phase, a person begins to enter a phase of development into a more mature human being to enter adulthood. In the age range of 26-30 years, it is classified as an early adult phase where a person begins to enter the adult phase and begins to learn to be more responsible for others. ${ }^{10}$ At this early adult stage, a person's cognitive abilities are at the prime stage, namely when a person will find it easier to learn, do logical reasoning, think creatively. There has not been a memory decline. ${ }^{11}$ Increasing a person's age will result in changes in psychological and psychological aspects due to the maturation of organ functions so that a person's level of thinking becomes more mature and mature. ${ }^{12}$

The Relationship Between Years of Service and Compliance with The Use of Personal Protective Equipment

The results of the correlation analysis to test the second hypothesis (H2) is a p-value of 0.75 , which means that the length of service is not related to compliance with the use of personal protective equipment, so that $\mathrm{HO}$ is rejected. The results of this study are following research conducted by Ibrahim, which shows that there is no significant relationship between years of service and the level of compliance with the use of gloves in clinical laboratory workers in Cilegon. ${ }^{9}$

The results of this study are not in line with the research conducted by Wibowo ${ }^{13}$ with the result that there is a significant relationship between tenure and compliance with the use of gloves during invasive procedures in the inpatient room of RSUD Dr. H. Soewondo Kendal. ${ }^{13}$ Another contradictory study is the research conducted by Al Maweri which states that dental students at Al Farabi University, Riyadh, Saudi Arabia, with longer tenures, have higher infection prevention adherence rates than entry-level students. ${ }^{14}$

Gibson states that experience affects individual behavior and work performance. The longer a person's working period, the more skills will increase because they have adapted to their work. ${ }^{15}$ However, Adhytyo states that someone with a more extended working period sometimes decreases their productivity due to boredom, so that the level of compliance can also decrease. ${ }^{16}$

From the study results, it can be seen that the compliance of nurses at RSU Royal Prima is not influenced by the length of service or the period of their profession. Furthermore, there is no difference in behavior in using personal protective equipment for respondents with a more extended working period or who have just entered work. This because they have been provided with the knowledge of the importance of using personal protective equipment in infection prevention measures.

The Relationship of Knowledge to Compliance with The Use of Personal Protective Equipment

The results of hypothesis testing in this study state that knowledge is related to the level of compliance with the use of personal protective equipment with a p-value of 0.009 . This indicates that the higher the knowledge of dental profession students about personal protective equipment, the compliance of nurses and officers in using personal protective equipment is getting better.

The results of this study are in line with research conducted by Saputro, which shows that there is a relationship between knowledge and the use of personal protective equipment for workers in Klaten. ${ }^{17}$ Research conducted by Goje also states a relationship between knowledge and the application of universal precautions to nursing and midwifery students in Damaturu, Northeast Nigeria. ${ }^{18}$ On the other hand, the research conducted by Liswanti ${ }^{18}$ stated that there is no relationship between knowledge and compliance with the use of personal protective equipment in professional students at the University of 
Indonesia. ${ }^{18}$ Research conducted by Labrague on students of the nursing profession in the Philippines also shows no relationship between knowledge and personal protective equipment. $^{20}$

According to Bloom, knowledge is an important domain to shape one's actions (over behavior). The higher one's health knowledge, the higher one's awareness to participate. ${ }^{4}$ Meanwhile, Green stated that increasing the level of knowledge does not always cause behavioral changes. However, the positive relationship between the two variables is often seen in several studies conducted. ${ }^{4}$ Knowledge of personal protective equipment is essential before taking action to use personal protective equipment. However, compliance with personal protective equipment will not just happen, except when someone gets a stronger incentive to motivate someone to act according to their knowledge.

Relationship Between Attitudes Towards Compliance with The Use of Personal Protective Equipment

The results of hypothesis testing conducted in this study show a relationship between attitude and compliance with the use of personal protective equipment at Royal Prima Hospital with a p-value of 0.002 . Bloom stated that behavior is one of the predisposing factors, namely, one factor in the individual in which there is an individual's attitude.

Attitude can affect a person's compliance in using personal protective equipment in a hospital because a person's attitude will be the beginning of behavior formation. ${ }^{21}$ This is also in line with research conducted by Riyanto, which states a relationship between attitude factors and nurse compliance in the use of PPE at Sari Asih Hospital Serang, Banten Province. ${ }^{22}$ This is also in line with the research conducted by Baseer, which states that attitude is correlated with compliance with dentists' use of personal protective equipment at a dental clinic in Riyadh, Saudi Arabia. ${ }^{23}$ On the other hand, the study results are not in line with the research conducted by Sihombing, with the result that there is no relationship between attitude and the use of personal protective equipment. ${ }^{24}$
The nurses and officers at RSU Royal Prima have a high average attitude. This high attitude becomes the basis for forming behavior that complies with respondents' protective equipment increase. Attitude in a job is essential to make good decisions that will result in a positive attitude and good behavior. This positive attitude also shows that respondents use personal protective equipment because they know the risks that will arise if they do not use personal protective equipment entirely and avoid transmitting infectious diseases.

The Relationship Between the Availability of Facilities and Compliance with The Use of Personal Protective Equipment

The results of this study indicate that the availability of facilities has a significance value of 0.000 , so it can be concluded that the availability of facilities has a significant relationship with compliance with the use of personal protective equipment at Royal Prima Hospital. Green stated that one factor influencing behavior is an enabling factor, one of which is the availability of facilities, which is the availability of good and complete personal protective equipment. The availability of personal protective equipment is one way to facilitate respondents to use complete personal protective equipment to carry out maintenance actions.

This is in line with research conducted by Putri, which states a relationship between the availability of personal protective equipment facilities and compliance with using personal protective equipment as one of the applications of universal precautions in RSUP DR. Djamil Padang. ${ }^{25}$ Another supporting research is research conducted by Ibrahim, which also shows a relationship between the availability of facilities and compliance with gloves for clinical laboratory workers in Cilegon. ${ }^{9}$ On the other hand, the results of this study are not following research conducted by Apriliuana which states that the availability of personal protective equipment is not related to compliance with the use of personal protective equipment. ${ }^{8}$ It is also not in line with Wuisan's research on nurses at Dr. Hospital. Kandou Manado shows no relationship between the availability of 
facilities and adherence to infection prevention behavior. ${ }^{26}$ The availability of easily obtained facilities and can be utilized is essential to shape behavior. Constantly the availability of supporting facilities will bring up a person's positive behavior. ${ }^{27}$

Relationship of Training to Compliance with The Use of Personal Protective Equipment

The results of this study's analysis indicate a relationship between training and compliance with the use of personal protective equipment at RSU Royal Prima with a p-value of 0.004 . Training is one form of learning that will produce a learning experience that can lead to behavioral changes so that the training provided can change a person's behavior. ${ }^{4}$ This is in line with research by Arlina, who researched emergency room staff at RSM Ahmad Dahlan with the results that there was an effect of training on compliance with the use of personal protective equipment. ${ }^{28}$ In line with research conducted by Haridi on dentists in Saudi Arabia, there is a relationship between training and compliance with the use of personal protective equipment. ${ }^{29}$

Royal Prima General Hospital organizes regular training on infection prevention and control, including personal protective equipment. The training provided can be a provision to increase respondents' knowledge which can improve the behavior of using personal protective equipment during service actions to patients.

Supervision Relationship to Compliance with The Use of Personal Protective Equipment

From the analysis results, it was found that there was a relationship between the supervision carried out on the compliance with the use of personal protective equipment. This is in line with research conducted by Yulita, which states that there is a significant effect of supervision on compliance with personal protective equipment for nurses at the Regional General Hospital of the Riau Islands Province. A similar study was also conducted by Riyanto, which stated a relationship between supervision and nurse compliance at the Sari Asih Hospital, Banten. ${ }^{22}$
According to Green in Notoatmodjo, supervisory factors can increase motivation in changing a person's behavior. The existence of good supervision can increase selfawareness to shape one's behavior so that all institutions must carry out consistent supervision. The hospital performs a supervisory function through the Hospital Infection Prevention and Control Team, which is tasked with carrying out periodic supervision of the compliance with the use of personal protective equipment for the entire hospital community at the Royal Prima General Hospital. Supervision is carried out regularly once a month to oversee compliance with the implementation of infection prevention and control, including compliance with the use of personal protective equipment. ${ }^{4}$

\section{CONCLUSION}

The variables of age, knowledge, attitude, availability of facilities, training, and supervision were positively related to compliance with personal protective equipment at RSU Royal Prima. On the other hand, the length of service variable is not related to compliance with personal protective equipment. Hospital management can hold regular socialization and routine training on Infection Prevention and Control to increase knowledge about the importance of using personal protective equipment. The hospital must also increase the availability of personal protective equipment facilities and carry out routine monitoring of compliance with personal protective equipment. Other variables can be added or additional types of respondents to the entire hospital community at the Royal Prima General Hospital for further research development.

\section{REFERENCES}

1. Zaenab ZLTSN. Problem dan Tantangan Puskesmas dan Rumah Sakit Umum Daerah dalam Mendukung Sistem Rujukan Maternal di Kabupaten Karimun Provinsi Kepri Tahun 2012. Jurnal Kebijakan Kesehatan Indonesia: JKKI. 2(4).

2. Firmansyah AT. Pemeriksaan Bakteri Total Udara Dan Kuman 
Staphyilococcus Aureus Dalam Ruang Operasi Di Rumah Sakit Umum Daerah Kota Semarang [PhD Thesis]. Diponegoro University; 2007.

3. World Health Organization (WHO). WHO Guideline on Hand Hygiene in Health Care [Internet]. 2009. Tersedia pada: http://whqlibdoc.who.int.

4. Notoadmodjo S. Promosi kesehatan dan ilmu perilaku. Jakarta: Rineka Cipta; 2007.

5. Masyhuri MZ. Metodologi penelitian pendekatan praktis dan aplikatif. Bandung: PT Refika Aditama; 2008.

6. Balbeid M, Rachmi AT, Alamsyah A. Pengaruh Pengetahuan Dan Sikap Dokter Dan Perawat Terhadap Kesiapan Berubah Dalam Menerapkan Clinical Pathway. E-Prodenta Journal of Dentistry. 2018;2(1):98-107.

7. Supiana N, Mufdlilah M. Hubungan Predisposing Enabling dan Einforcing Faktor dengan Penggunaan APD (Alat Pelindung Diri) pada Bidan dalam Pelayanan Kebidanan di Rumah Sakit KIA Sadewa Yogyakarta Tahun 2013 [PhD Thesis]. STIKES'Aisyiyah Yogyakarta; 2013.

8. Apriluana G, Khairiyati L, Setyaningrum R. Hubungan antara usia, jenis kelamin, lama kerja, pengetahuan, sikap dan ketersediaan alat pelindung diri (APD) dengan perilaku penggunaan APD pada tenaga kesehatan. Jurnal Publikasi Kesehatan Masyarakat Indonesia. 2016;3(3).

9. Ibrahim B. Tingkat Kepatuhan Penggunaan Sarung Tangan Dalam Kaitan Standar Kewaspadaan Umum Bagi Petugas Laboratorium Klinik Kota Cilegon Tahun 2009. Skripsi Jakarta: Fakultas Kesehatan Masyarakat Universitas Indonesia. 2009;

10. Depkes RI. Profil Kesehatan Indonesia. Jakarta: Departemen Republik Indonesia; 2009.

11. Potter P, Perry AG. Fundamental Of Nursing: Consep, Proses and Practice. Edisi; 2010.

12. Mubarak. Promosi Kesehatan. Yogyakarta: Graha; 2007.
13. Wibowo AS, Suryani M. Hubungan Karakteristik Perawat Dengan Penggunaan Sarung Tangan Pada Tindakan Ivasif Di Ruang Rawat Inap Rsud Dr. H. Soewondo Kendal. Karya Ilmiah. 2013;

14. Al-Maweri SA, Tarakji B, ShugaaAddin B, Al-Shamiri HM, Alaizari NA, AlMasri O. Infection control: Knowledge and compliance among Saudi undergraduate dental students. GMS hygiene and infection control. $2015 ; 10$.

15. Gibson JL. Organisasi dan Manajemen. Jakarta: Erlangga; 1997.

16. Adhytyo DR. Reliabilitas Mempengaruhi Kepuasan Pasien Terhadap Pelayanan Kesehatan di salah satu Puskesmas Kabupaten Ngawi. Gaster. 2013;10(2):22-32.

17. Saputro VA. Hubungan Antara Pengetahuan dan Sikap Dengan Penggunaan Alat Pelindung Diri (APD) Pada Pekerja Di Unit Kerja Produksi Pengecoran Logam [PhD Thesis]. Universitas Muhammadiyah Surakarta; 2015.

18. Goje M, Balami AD, Jarma M, Dauda S. Knowledge, attitude, self-efficacy and practice of standard precaution measures by nursing and midwifery students in Damaturu, North-Eastern Nigeria. Nursing. 2018;69:55-2.

19. Liswanti Y. Hubungan Tingkat Pengetahuan dan Sikap Dengan Perilaku Penggunaan Alat Pelindung Diri Pada Mahasiswa Prodi DIII Analis Kesehatan STIKes BTH Tasikmalaya. Jurnal Kesehatan Bakti Tunas Husada: Jurnal Ilmu-ilmu Keperawatan, Analis Kesehatan dan Farmasi. 2018;17(2):502-512.

20. Labrague LJ, Rosales RA, Tizon MM. Knowledge of and compliance with standard precautions among student nurses. International journal of advanced nursing studies. 2012;1(2):84-97.

21. Dayakisni H. Psikologi sosial. Malang: UMM Press; 2003.

22. Riyanto DA. Faktor- Faktor Yang Mempengaruhi Kepatuhan Perawat Dalam Penggunaan Alat Pelindung Diri 
Di Rumah Sakit Sari Asih Serang Provinsi Banten. Jurnal. STIKES Santo Boromeus. Jurnal STIKES Santo Boromeus. 2014;

23. Baseer M-A, Ansari S-H, AlShamrani SS, Alakras A-R, Mahrous R, Alenazi A$M$. Awareness of droplet and airborne isolation precautions among dental health professionals during the outbreak of corona virus infection in Riyadh city, Saudi Arabia. Journal of clinical and experimental dentistry. 2016;8(4):e379.

24. Sihombing FD. Faktor-faktor yang mempengaruhi pemakaian alat pelindung diri (APD) pada pekerja "stimulasi" di unit penderesan PT Socfin Indonesia Tanah Besih Tahun 2014. Artikel penelitian Medan: Fakultas Kesehatan Masyarakat Universitas Sumatera Utara. 2014;

25. Putri KDS, Denny Y. Analisis faktor yang berhubungan dengan kepatuhan menggunakan alat pelindung diri. The Indonesian Journal of Occupational Safety, Health and Environment. 2014;1(1):24-36.

26. Wuisan C, Rampengan SH, Korompis $\mathrm{M}$. Factors related to the implementation of universal precautions by nurses in the inpatient unit (IRINA F) Prof. Dr. RD Kandou Central General Hospital Manado. Bali Medical Journal. 2017;6(1):68-72.

27. Azwar. Pengantar Ilmu Kesehatan Lingkungan. Jakarta: Mutiara; 1983.

28. Arlina D, Ellafina O. Evaluasi Penggunaan Alat Pelindung Diri Pada Petugas Igd (Studi Kasus Di Rsm Ahmad Dahlan Kediri). Naskah Publikasi. 2015;

29. Haridi HK, Al-Ammar AS, Al-Moazzy IM. Knowledge of dental health care workers about standard precautions guidelines at health care facilities in Hail Region, Saudi Arabia. International Journal of Advanced Research (IJAR). 2016;4:1375-1385. 